\title{
Trends in Body Height, Body Weight, BMI, and Nutrition Status from 1979 to 1987: A Measurement-Based Analysis of 10,954 Male Adolescents from the Municipality of Bijelo Polje
}

Tendencias en la Altura Corporal, el Peso Corporal, el IMC y el Estado Nutricional de 1979 a 1987: un Análisis Basado en Mediciones de 10.954 Adolescentes Varones del Municipio de Bijelo Polje

\author{
Bojan Masanovic ${ }^{1,2}$; Dusko Bjelica ${ }^{1,2}$; Zoran Milosevic ${ }^{3}$; Marin Corluka ${ }^{4}$ \& Jovan Garasevic ${ }^{1,2}$
}

\begin{abstract}
MASANOVIC, B.; BJELICA, D.; MILOSEVIC, Z.; CORLUKA, M. \& GARASEVIC, J. Trends in body height, body weight, bmi, and nutrition status from 1979 to 1987: A measurement-based analysis of 10,954 male adolescents from the municipality of Bijelo Polje. Int. J. Morphol., 39(4):1036-1041, 2021.

SUMMARY: This study aimed to consolidate data regarding body height, body weight, body mass index, and nutrition status of the entire young male population from the Municipality of Bijelo Polje in order to estimate trends from 1979 to 1987 . The sample of respondents includes 10,954 young males divided into nine groups. The measurement sample includes body height, body weight, and body mass index based on two previous measures. The descriptive statistics were expressed as a mean and standard deviation for each variable, while the analysis of nutrition status was done based on body mass index (underweight, normal weight, pre-obese, obese). The results showed that a secular trend in the observed study period is not visible regarding body height, body weight, and body mass index. The contribution of this study is reflected in the fact that there were no previously published data for this period and this municipality; the data can significantly aid in monitoring the secular trends throughout Montenegro.
\end{abstract}

KEY WORDS: Morphological characteristics; Secular trend; Young males; Montenegro.

\section{INTRODUCTION}

Intergenerational changes in body dimensions have occupied anthropologists' attention for centuries (NCD Risk Factor Collaboration, 2016; Kalka et al., 2019; Starc et al., 2019). The available data emphasize progressive changes of somatic characteristics throughout the world, including in Montenegro (Cardoso \& Caninas, 2010; Bielecki et al., 2012; Popovic, 2017; Masanovic et al., 2019a). Scientists cite the improvement of social and economic conditions as the reason for these changes (Hauspie et al., 1996; Popovic et al., 2020a).

In Montenegro, which is historically recognized as a habitat of above-average tall people (Bjelica et al., 2012; Milasinovic et al., 2016a,b; Grasgruber et al., 2017, 2019), an increase in body height is also observable comparing average values at the beginning of the 20th century (Coon, 1939) with those from the 21st century (Popovic, 2017). However, increasing the average values of body height of successive generations is often considered to be a positive change, because some sources state that taller people may be more successful in school, earn more money, get better work positions, and similar (Popovic, 2018). Of course, it should not be forgotten that height can significantly impact success in some sports disciplines (Monson et al., 2018; Masanovic, 2019b; Bjelica et al., 2020). In contrast, the increased percentage of people with obesity and overweight that is well documented is certainly a negative change (Woodward et al., 2001; NCD Risk Factor Collaboration, 2017; Banjevic et al., 2020), because overweight increases the risk of cardiovascular diseases and chronic disorders, and represents significant medical and socioeconomic burdens in the world today (Woodward et al.; Singh et al., 2008; Popovic \& Masanovic, 2019; Rezaeipour et al., 2021).

Although there are studies on the basis of which the trend of body height in Montenegro can be described (Coon; Popovic, 2017), there is a multi-decade gap of quality data,

\footnotetext{
${ }^{1}$ University of Montenegro, Faculty for Sport and Physical Education, Niksic, Montenegro.

${ }^{2}$ Montenegrin Sports Academy, Podgorica, Montenegro.

${ }^{3}$ University of Novi Sad, Faculty of Sport and Physical Education, Novi Sad, Serbia.

${ }^{4}$ University of Mostar, Faculty of Mathematics and Science Education, Mostar, Bosnia and Herzegovina.
} 
which will be alleviated by this study. For obesity and overweight, a lack of trend data is observed; therefore, this study's information is needed to create appropriate policies for health-care systems.

Therefore, this study aims to brings together the data on body height, body weight, and body mass index of the entire young male population of the Municipality of Bijelo Polje, which is the largest city in the northern region of Montenegro, to evaluate the trends from 1979 to 1987 , for the purpose of collecting information on possible acceleration, as well the changes of nutrition status in young males.

\section{MATERIAL AND METHOD}

This study's population contains all young male citizens of the Municipality of Bijelo Polje, measured during mandatory medical examinations to test their ability for military service.

Future recruits underwent this examination, preferably before the age of 18 , although military service could be postponed until the age of 27 ; some had their medical examinations later, which increased the average age in each generation.

In the period from 9 October 1979 to 17 November 1987, 11,028 future recruits of the Yugoslav People's Army with permanent residence in Bijelo Polje underwent this examination, but young males born in 1952 (1 respondent), 1957 (5 respondents), 1958 (9 respondents), 1959 (39 respondents) and 1960 (20 respondents) were excluded from the analysis because their numbers were not sufficient for their entire generation's characteristics to be reliably described. Consequently, the analysed data in this study covers the sample of $10,954(18.05 \pm .33)$ future recruits divided into nine groups: 1267 respondents born in 1961

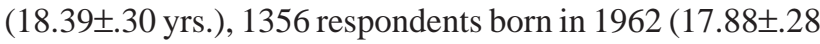
yrs.), 1591 respondents born in 1963 (17.78土.20 yrs.), 615 respondents born in 1964 (17.76 .17 yrs.), 994 respondents born in 1965 (17.79 \pm .32 yrs.), 1227 respondents born in 1966

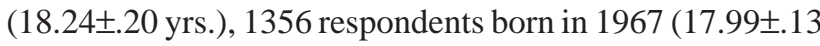
yrs.), 1118 respondents born in 1968 (18.39 \pm .22 yrs.), and 1430 respondents born in 1969 (18.14 .23 yrs.).

Anthropometric measurement was implemented in medical infirmaries, and respondents accessed the procedure in their underwear. From the sample measures collected for this research, body height and body weight are isolated; the body mass index is calculated using them. For body height and body weight assessment, a medical scale with moving weights with a stadiometer was used. Anthropometrical measurement was implemented by respecting the basic rules and principles of the International Biological Program (IPB), and the body mass index was calculated based on the protocol handbook for physical form assessment connected to health (American College of Sports Medicine, 2013).

The data obtained in the research were processed using SPSS 20.0 software (Chicago, IL, USA) adjusted for use on personal computers. The descriptive statistics were expressed as a mean and standard deviation for each variable, while post-hoc test with ANOVA were employed to explore differences between the means. The analysis of nutrition status was done based on body mass index (underweight, normal weight, pre-obese, obese) (World Health Organization, 2010).

\section{RESULTS}

Analysis of the average body height, body mass, and body mass index of young male subjects is shown in Table I. The average body height of the overall sample of male

Table I. Descriptive data of young male from Bijelo Polje enrolled in the study.

\begin{tabular}{lcccc}
\hline & \multicolumn{3}{c}{ Mean \pm SD } \\
\cline { 2 - 5 } Year of birth & Age $(\mathrm{yrs})$. & Body Height $(\mathrm{cm})$ & Body Weight $(\mathrm{kg})$ & $\begin{array}{c}\text { Body Mass } \\
\text { Index }\left(\mathrm{kg} / \mathrm{m}^{2}\right)\end{array}$ \\
\hline $1961(\mathrm{n}=1267)$ & $18.39 \pm 0.30$ & $175.65 \pm 6.69$ & $67.16 \pm 7.80$ & $21.77 \pm 2.23$ \\
$1962(\mathrm{n}=1356)$ & $17.88 \pm 0.28$ & $174.78 \pm 6.32$ & $65.91 \pm 8.06$ & $21.55 \pm 2.12$ \\
$1963(\mathrm{n}=1591)$ & $17.78 \pm 0.20$ & $175.50 \pm 6.80$ & $66.12 \pm 8.47$ & $21.45 \pm 2.28$ \\
$1964(\mathrm{n}=615)$ & $17.76 \pm 0.17$ & $176.37 \pm 6.47$ & $66.60 \pm 8.19$ & $21.38 \pm 2.15$ \\
$1965(\mathrm{n}=994)$ & $17.79 \pm 0.32$ & $174.89 \pm 6.42$ & $65.53 \pm 8.13$ & $21.39 \pm 2.08$ \\
$1966(\mathrm{n}=1227)$ & $18.24 \pm 0.20$ & $176.96 \pm 6.10$ & $66.77 \pm 8.16$ & $21.32 \pm 2.34$ \\
$1967(\mathrm{n}=1356)$ & $17.99 \pm 0.13$ & $176.47 \pm 6.63$ & $66.92 \pm 8.91$ & $21.47 \pm 2.44$ \\
$1968(\mathrm{n}=1118)$ & $18.39 \pm 0.22$ & $175.78 \pm 6.65$ & $67.52 \pm 8.36$ & $21.83 \pm 2.22$ \\
$1969(\mathrm{n}=1430)$ & $18.14 \pm 0.23$ & $175.56 \pm 6.64$ & $66.99 \pm 8.62$ & $21.73 \pm 2.50$ \\
$1961-1969(\mathrm{n}=10954)$ & $18.05 \pm 0.33$ & $175.74 \pm 6.57$ & $66.62 \pm 8.35$ & $21.55 \pm 2.29$ \\
\hline
\end{tabular}


subjects was $175.74 \pm 6.57$ centimetres. The tallest group were respondents born in 1966 (176.96 \pm 6.10$)$, while the shorter ones were respondents born in $1962(174.78 \pm 6.32)$. The average body weight of the overall sample of male subjects was $66.62 \pm 8.35 \mathrm{~kg}$, while the heaviest respondents were those born in 1968 (67.52 \pm 8.36$)$, and the least heavy were respondents from the group born in 1965 (65.53 \pm 8.13$)$. The average body mass index of the overall sample of male subjects was $21.55 \mathrm{~kg} / \mathrm{m}^{2}$, while the highest values had respondents of the group born in 1968 (21.83), and the lowest values had respondents of the group born in 1966 (21.32). The post-hoc test with ANOVA were employed to explore differences between the means and no statistically significant difference between study groups were found.

Trends in mean body height, body weight, and body mass index (BIM) by year of birth are presented graphically (Figs. 1, 2, and 3).

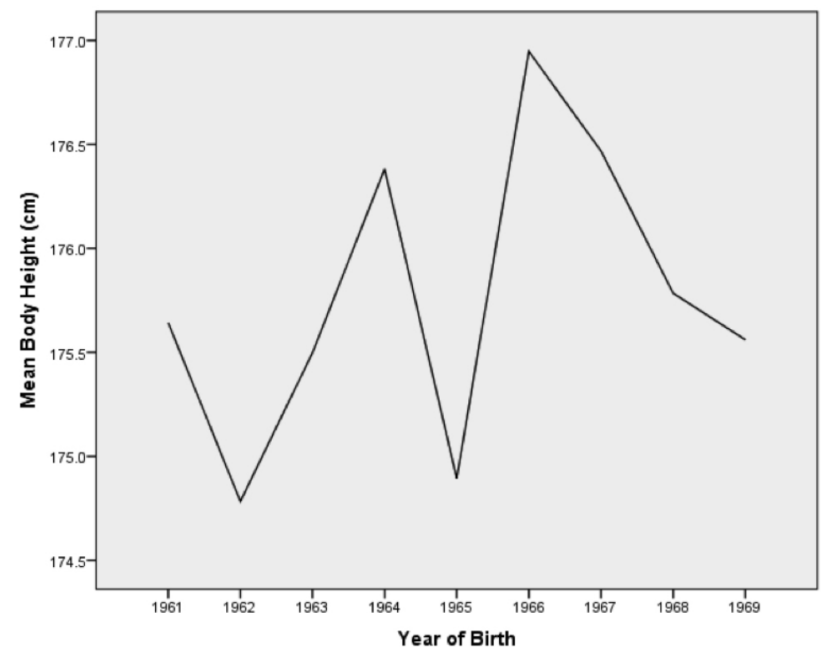

Fig. 1. Trends in mean body height by year of birth in young males.

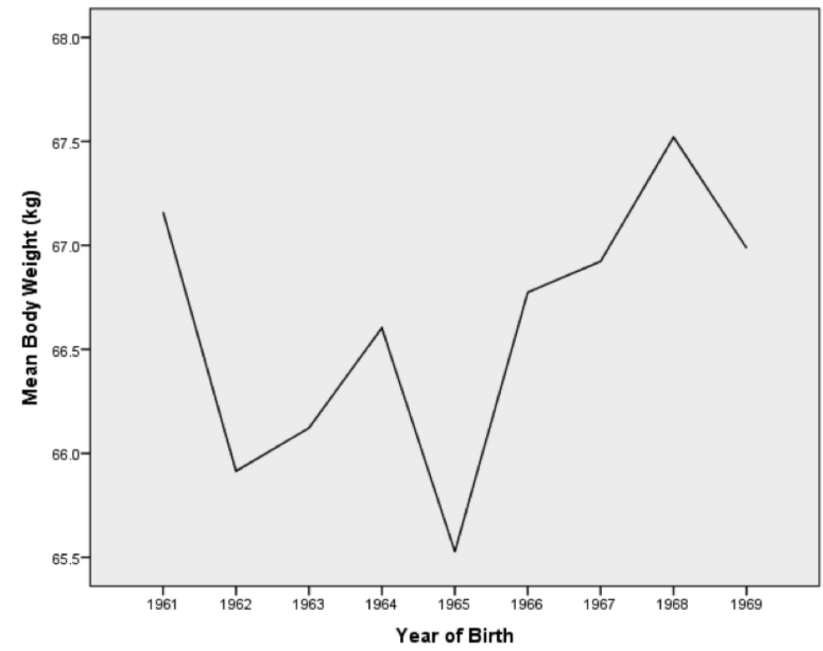

Fig. 2.Trends in mean body weight by year of birth in young males.



Fig. 3. Trends in mean body mass index (BMI) by year of birth in young males.

Table II. The Nutrition status by age and total for the young male enrolled in the study

\begin{tabular}{|c|c|c|c|c|c|c|c|c|c|}
\hline \multirow[t]{2}{*}{ Year of birth } & Total & Underweight & \multicolumn{3}{|c|}{ Normal weight } & Pre-obese & \multicolumn{3}{|c|}{ Obese } \\
\hline & $\mathrm{n}$ & $\mathrm{n}$ & $\%$ & $\mathrm{n}$ & $\%$ & $\mathrm{n}$ & $\%$ & $\mathrm{n}$ & $\%$ \\
\hline 1961 & $(n=1267)$ & 47 & 3.71 & 1150 & 90.77 & 62 & 4.89 & 8 & 0.63 \\
\hline 1962 & $(n=1356)$ & 72 & 5.31 & 1211 & 89.31 & 68 & 5.01 & 5 & 0.37 \\
\hline 1963 & $(n=1591)$ & 120 & 7.54 & 1372 & 86.24 & 93 & 5.85 & 6 & 0.38 \\
\hline 1964 & $(n=615)$ & 40 & 6.5 & 542 & 88.13 & 32 & 5.2 & 1 & 0.16 \\
\hline 1965 & $(n=994)$ & 64 & 6.44 & 876 & 88.13 & 53 & 5.33 & 1 & 0.1 \\
\hline 1966 & $(n=1227)$ & 93 & 7.58 & 1063 & 86.63 & 63 & 5.13 & 8 & 0.65 \\
\hline 1967 & $(n=1356)$ & 112 & 8.26 & 1150 & 84.81 & 85 & 6.27 & 9 & 0.66 \\
\hline 1968 & $(n=1118)$ & 52 & 4.65 & 985 & 88.1 & 77 & 6.89 & 4 & 0.35 \\
\hline 1969 & $(n=1430)$ & 92 & 6.43 & 1216 & 85.03 & 109 & 7.62 & 13 & 0.91 \\
\hline 1961-1969 & $(n=10954)$ & 692 & 6.32 & 9565 & 87.32 & 642 & 5.86 & 55 & 0.5 \\
\hline
\end{tabular}


From Table II, it can be observed that, in the overall sample of subjects, $6.32 \%$ were underweight, $87.32 \%$ has normal weight, $5.86 \%$ were pre-obese, and $0.5 \%$ were obese. The highest percentage of underweight is in the group of respondents born in $1967(8.26 \%)$, while the lowest percentage is in the group of respondents born in 1961 (3.71 $\%)$. The highest percentage of respondents with normal body weight is in the group of respondents born in 1961 (90.77 $\%$ ), while the lowest percentage is in the group of respondents born in $1967(84.81 \%)$. The highest percentage of preobesity is in the group of respondents born in 1969 (7.62 $\%$ ), while the lowest percentage is in the group of respondents born in 1961 (4.89\%). Lastly, the highest percentage of obesity is in the group of respondents born in 1969 (0.91 $\%$ ), while the lowest percentage is in the group of respondents born in $1965(0.1 \%)$.

Trends in all categories of nutrition status (underweight, normal weight, pre-obese, obese) by year of birth are presented (Fig. 4).

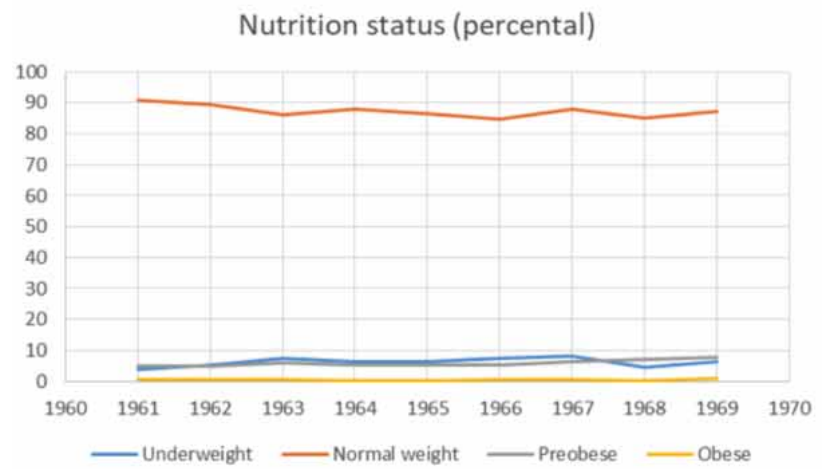

Fig. 4. Trends in the nutrition status by year of birth in young males.

\section{DISCUSSION}

The existence of a secular trend in the world, including in Montenegro, is indisputable, and it is confirmed by numerous studies (Schmidt et al., 1995; Cardoso \& Caninas; Lissner et al., 2013; Popovic, 2017), which means that this study does not strive to prove it, because this has long been accomplished. Its purpose is to present new data, which were necessary to accurately monitor the rate of change in the average body height of young Montenegrins in the previous 120 years. Thus, a more precise understanding of the periods in which the positive secular changes were higher and in which they were less pronounced will be created.

Considering that at the beginning of the 20th century, the average body height of young Montenegrins, according to
Robert Ehrich, was $177 \mathrm{~cm}$ (Coon) and $183.36 \mathrm{~cm}$ at the beginning of the 21 st century (Popovic, 2017), it is concluded that for this period body height has increased by $6.36 \mathrm{~cm}$ in average. However, it is not known in which period the increase in height becomes more noticeable.

From 1979 to 1987, young Montenegrins enrolled in this study were, on average, $175.74 \mathrm{~cm}$ tall, which is $1.26 \mathrm{~cm}$ lower than the average body height of Montenegrins recorded at the beginning of the century. However, it must be taken into account that the subjects included in this study had an average age of $18.05 \mathrm{yrs}$. $( \pm 0.33)$, and that their body height had not yet peaked. If the measurement had been made one or two years later, their stature would surely have been somewhat higher. These data lead to the conclusion that from the beginning of the 20th century until 1987, the secular trend in Montenegro was not noticeable. A review of the previous literature shows that this is possible because the trends in male mean body height in 15 Western European countries showed that there were positive secular trends in the second half of the 20th century ranging from 0.26 to $2.53 \mathrm{~cm}$ per decade, but the course of changes in body height in the population was not the same over the entire period studied (LopuszanskaDawid et al., 2020). The mentioned study does not specify when the rate of secular trend is the highest, but it points to regional differences and the connection with living conditions.

Taking into account the above, it can be concluded that the rate of secular trend is higher in the 1990s and beyond than was the case until 1987. The reason may be that the inhabitants of this region participated in four wars between 1912 and 1945, followed by more than two decades of poor life and state-building. This is confirmed by the data that in SFR Yugoslavia, of which Montenegro was an integral part: from the beginning of the 1960s to the end of the 1980s, 100150,000 apartments were built annually, and it was necessary to wait until the late ' 70 s and early ' 80 s, for all households to become electrified, connected to water supply and sewage system, and have a bathroom and toilet as part of the apartment (Beslin et al., 2017).

If only the period covered by this study is observed (from 1979 to 1987), changes in body height are not visible, which is logical, because a nine-year period is too short for a noticeable secular trend (Hitka et al., 2018; LopuszanskaDawid et al.).

Furthermore, it is interesting to compare the average body weight and body mass index of respondents from this study (measured from 1979 to 1987), whose value is $66.62 \pm 8.35 \mathrm{~kg}$ for body weight and $21.55 \pm 2.29 \mathrm{~kg} / \mathrm{m}^{2}$ for body mass index, with respondents measured by Gardasevic et al. (2015), also on a sample of Montenegrin adolescents. Twenty- 
MASANOVIC, B.; BJELICA, D.; MILOSEVIC, Z.; CORLUKA, M. \& GARASEVIC, J. Trends in body height, body weight, bmi, and nutrition status from 1979 to 1987: A measurement-based analysis of 10,954 male adolescents from the municipality of Bijelo Polje. Int. J. Morphol., 39(4):1036-1041, 2021.

eight years later, Gardasevic et al. (2015), measured significantly higher values for both parameters. The average body weight value of respondents from their study was 79.37 $\mathrm{kg}$ (17 yrs.) and $78.5 \mathrm{~kg}$ (18 yrs.), and the average body mass index value was $24.9 \mathrm{~kg} / \mathrm{m}^{2}$ (17 yrs.) and $22.8 \mathrm{~kg} / \mathrm{m}^{2}$ (18 yrs.), based on which it can be concluded that the secular trend is also evident here. The changes in average body weight, body mass index value, and global obesity frequency increased for children and adolescents in the previous 40 years (NCD Risk Factor Collaboration, 2017). According to the results NCD Risk Factor Collaboration study (2017), in that period, in 189 countries, the average body mass index value increased for young male respondents by more than $0.05 \mathrm{~kg} / \mathrm{m} \sum$ every 10 years. Furthermore, obesity in the previous 40 years, for children and adolescents, increased from $0.9 \%$ to $7.8 \%$, and lastly, the percentage of underweight for young males decreased from $14.8 \%$ to $12.4 \%$.

The present study's results in the period from 1979 to 1987 do not show a linear increase in body mass index values of young male Montenegrins, but it is interesting to add that the percentage of respondents with normal weight constantly decreases from 1979 to 1987, while the percentage of the preobese increased proportionately (Fig. 4); consequently, we can conclude that the secular trend is also evident here, despite being a short period of only nine years.

It is important to emphasize that this study has certain limitations. The first is the fact that respondents' average age was 18.05 years, which practically means that the majority of them were underage at the time of measurement, so it can be reasonably concluded that at the time of measurement, they had not yet completed growing (Popovic et al., 2020b). Considering this fact, it is assumed that their body height, body weight, and body mass index data would progress and would have been taller and heavier if they were measured one year later. Consequently, data about their final characteristics are not completely reliable. The second limitation is the fact that the measured inhabitants of only one city in Montenegro and that the results would be more objective if the sample included other cities. However, the size of the sample, which includes 10,954 respondents, and the fact that it is the most populous city in the northern Montenegrin region, give this study sufficient credibility. The strength of this study is that it covers a complete sample of the population of this city and gives a clear picture of what the situation was in Bijelo Polje on this issue in the 1980s. Also, in combination with similar studies published for Cetinje, Niksic, Bar. And Podgorica (Popovic et al., 2020a,b; Masanovic et al., 2020; Gardasevic et al., 2020; Vasiljevic et al., 2020), when the data for other Montenegrin municipalities will be published, the strength of this study will be even greater, because there will be a clear picture of the situation in the whole country.

\section{AUTHOR CONTRIBUTIONS}

Bojan Masanovic designed and led the study, performed statistical analyses and wrote the manuscript; Dusko Bjelica wrote manuscript and discussed the results. Zoran Milosevic overviewed previous studies and discussed the results. Marin Corluka overviewed previous studies and discussed the results. Jovan Gardasevic collected the data, did the presentation of the results, discussed the results and revised the manuscript.

MASANOVIC, B.; BJELICA, D.; MILOSEVIC, Z.; CORLUKA, M. \& GARASEVIC, J. Tendencias en la altura corporal, el peso corporal, el IMC y el estado nutricional de 1979 a 1987: un análisis basado en mediciones de 10.954 adolescentes varones del municipio de Bijelo Polje.Int. J. Morphol., 39(4):1036-1041, 2021.

RESUMEN: Este estudio tuvo como objetivo consolidar los datos sobre la altura corporal, el peso corporal, índice de masa corporal y el estado nutricional de toda la población masculina joven del Municipio de Bijelo Polje con el fin de estimar las tendencias de 1979 a 1987 . La muestra de encuestados incluyó 10.954 hombres jóvenes divididos en nueve grupos. Las mediciones incluyeron la altura corporal, el peso corporal y el índice de masa corporal basado en dos medidas anteriores. Las estadísticas descriptivas se expresaron como media y desviación estándar para cada variable, mientras que el análisis del estado nutricional se realizó con base en el índice de masa corporal (bajo peso, peso normal, pre-obesidad, obesidad). Los resultados mostraron que una tendencia secular en el período de estudio observado no es visible con respecto a la altura corporal, el peso corporal y el índice de masa corporal. La contribución de este estudio está basada en que no existían datos publicados previamente para este período y en este municipio; los datos pueden ayudar significativamente a monitorear las tendencias seculares en todo Montenegro.

PALABRAS CLAVE: Características morfológicas; Tendencia secular; Machos jóvenes; Montenegro.

\section{REFERENCES}

American College of Sports Medicine. ACSM's Health-Related Physical Fitness Assessment Manual. Boston, Wolters Kluwer, 2013.

Banjevic, B.; Popovic, S. \& Masanovic, B. Body mass index and body fat percentage of armed forces personnel in Montenegro among different age groups. Iran. J. Public Health, 49(5):1010-1, 2020.

Beslin, M.; Duda, I.; Gligorov, V.; Goldstein, I.; Jakovina, T.; Janceva, Lj.; Kamberovic, H.; Limani, M.; Litovski, A.; Makuljevic, N.; et al. Jugoslavija u istorijskojperspektivi. Beograd, Helsinski Odbor za Ljudska Prava u Srbiji, 2017.

Bielecki, E. M.; Haas, J. D. \& Hulanicka, B. Secular changes in the height of Polish schoolboys from 1955 to 1988. Econ. Hum. Biol., 10(3):3107, 2012. 
Bjelica, D.; Masanovic, B. \& Krivokapic, D. A comparative study of anthropometric measurements and body composition between junior football and basketball players from the Serbian National League. Balt. J. Health Phys. Act., 12(1):11-19, 2020.

Bjelica, D.; Popovic, S.; Kezunovic, M.; Petkovic, J.; Jurak, G. \& Grasgruber, P. Body Height and Its Estimation Utilizing Arm Span Measurements in Montenegrin Adults. Anthropol. Noteb., 18(2):69$83,2012$.

Cardoso, H. F. V. \& Caninas, M. Secular trends in social class differences of height, weight and BMI of boys from two schools in Lisbon, Portugal (1910-2000). Econ. Hum. Biol., 8(1):111-20, 2010.

Coon, C. The races of Europe. New York, Macmillan Publishers, 1939.

Gardasevic, J.; Martinovic, S.; Vasiljevic, I.; Bubanja, M.; Malovic, P. \& Vrevic, E. Analysis of trends in anthropometric characteristics of Montenegrin young men from Niksic from 1957 to 1969. Sport Mont, 18(2):55-9, 2020.

Gardasevic, J.; Vasiljevic, I.; Bjelica, D. \& Popovic, S. Analysis of nutrition of boys and girls, adolescents from Montenegro. J. Phys. Educ. Sport, 15(4):702-4, 2015.

Grasgruber, P.; Popovic, S.; Bokuvka, D.; Davidovic, I.; Hr`ebíckova, S.; Ingrova, P.: Potpara, P.; Prce, S. \& Stracarova, N. The mountains of giants: an anthropometric survey of male youths in Bosnia and Herzegovina. R. Soc. Open Sci., 4:161054, 2017.

Grasgruber, P.; Prce, S.; Stracarova, N.; Hrazdíra, E.; Cacek, J.; Popovic, S.; Hrebíckova, S.; Potpara, P.; Davidovic, I. \& Kalina, T. The coast of giants: an anthropometric survey of high schoolers on the Adriatic coast of Croatia. PeerJ, 7:e6598, 2019.

Hauspie, R. C.; Vercauteren, M. \& Susanne, C. Secular changes in growth. Horm. Res., 45 Suppl. 2:8-17, 1996.

Hitka, M.; Sedmák, R.; Joscák, P. \& Lizbetinová, L. Positive secular trend in Slovak population urges on updates of functional dimensions of furniture. Sustainability, 10(10):3474, 2018.

Kalka, E.; Pastuszak, A. \& Busko, K. Secular trends in body height, body weight, BMI and fat percentage in Polish university students in a period of 50 years. PloS One, 14(8):e0220514, 2019.

Lissner, L.; Mehlig, K.; Sjoberg, A.; Chaplin, J.; Niklasson, A. \& Albertsson-Wikland, K. Secular trends in weight, height and BMI in young Swedes: the "Grow up Gothenburg" studies. Acta Paediatr., 102(3):314-7, 2013.

Lopuszanska-Dawid, M.; Ko?odziej, H.; Lipowicz, A.; Szklarska, A.; Kopiczko, A. \& Bielicki, T. Social class-specific secular trends in height among 19-year old Polish men: 6th national surveys from 1965 till 2010. Econ. Hum. Biol., 37:100832, 2020.

Masanovic, B. Comparative study of morphological characteristics and body composition between different team players from Serbian Junior National League: soccer, handball, basketball and volleyball. Int . J. Morphol., 37(2):612-9, 2019a.

Masanovic, B.; Bavcevic, T. \& Prskalo, I. Regional differences in adult body height in Kosovo. Monten. J. Sports Sci. Med., 8(1):69-76, $2019 \mathrm{~b}$.

Masanovic, B.; Martinovic, S.; Zoric G.; Bacovic D.; Mitrovic, M. \&Vukotic, M. Trends in body height, body weight, and body mass index from 1979 to 1987: an analysis of the young male population from the municipality of Cetinje. J. Anthropol. Sport Phys. Educ., 4(2):3-7, 2020.

Milasinovic, R.; Popovic, S.; Matic, R.; Gardasevic, J. \& Bjelica, D. Body height and its estimation utilizing arm span measurements in male adolescents from southern region in Montenegro. Sport Mont, 14(2):21-3, 2016a.

Milasinovic. R.; Popovic, S.; Jaksic, D.; Vasilejvic, I. \& Bjelica, D. Stature and its estimation utilizing arm span measurements in feale adolescents from southern region in Montenegro. Sport Mont, 14(3):15-8, $2016 \mathrm{~b}$.

Monson, T. A.; Brasil, M. F. \& Hlusko, L. J. Allometric variation in modern humans and the relationship between body proportions and elite athletic success. J. Anthropol. Sport Phys. Educ., 2(3):3-8, 2018.

NCD Risk Factor Collaboration (NCD-RisC). A century of trends in adult human height. Elife, 5:e13410, 2016.
NCD Risk Factor Collaboration (NCD-RisC). Worldwide trends in bodymass index, underweight, overweight, and obesity from 1975 to 2016: a pooled analysis of 2416 population-based measurement studies in 128.9 million children, adolescents, and adults. Lancet, 390(10113):2627-42, 2017.

Popovic, S. \& Masanovic, B. Effects of physical and social activity on physical health and social inclusion of elderly people. Iran. J. Public Health, 48(10):1922-3, 2019.

Popovic, S. Arm-span measurement as an alternative estimation of true height in Montenegrin young adults of both sexes: a national survey. Anthropol. Noteb., 24(1):53-67, 2018.

Popovic, S. Local geographical differences in adult body height in Montenegro. Monten. J. Sports Sci. Med., 6(1):81-7, 2017.

Popovic, S.; Banjevic, B.; Masanovic, B. \& Bjelica, D. Body mass index and measures of body fat for defining obesity and underweight: a cross-sectional of various specialties in montenegrin army soldiers. Iran. J. Public Health, 49(12):2376-83, 2020a.

Popovic, S.; Masanovic. B.; Martinovic, S.; Bjelica, D. \& Gardasevic, J. Trajectories in body height, body weight, bmi, and nutrition status from 1979 to 1987: a measurement-based analysis of 15,717 male adolescents from the capital city of Montenegro. Front. Public Health, 8:610358, 2020b.

Rezaeipour, M.; Apanasenko, G. L. \& Raghi, Z. Efficacy of the WATERinMOTION aquatics exercise programme on the body weight and composition of sedentary older women with overweight/obesity. Monten. J. Sports Sci. Med., 10(2), 2021. DOI: https://www.doi.org/ 10.26773/mjssm.210903

Schmidt, I. M.; Jorgensen, M. H. \& Michaelson, K. Height of conscripts in Europe: is postneonatal mortalityba predictor. Ann. Hum. Biol., 22(1):57-67, 1995

Singh, A. S.; Mulder, C.; Twisk, J. W. R.; van Mechelen, W. \& Chinapaw, M. J. M. Tracking of childhood overweight into adulthood: a systematic review of the literature. Obes. Rev., 9(5):474-88, 2008.

Starc, G.; Popovic, S.; Dordic, V.; Ostojic, S.; Music Milanovic, S.; Kujundzic, E.; Spiroski, I.; Duric, S.; Masanovic, B.; Sember, V.; et al. Differences in body height between the contemporary Western Balkan children and the WHO growth references core sample. Anthropol. Noteb., 25(3):55-67, 2019.

Vasiljevic, I.; Martinovic, S.; Gardasevic, J.; Bubanja, M.; Malovic, P.; Vrevic, E. \& Redzepagic, S. Analysis of trends in anthropometric characteristics of Montenegrin recruits from bar in period from 1979 to 1987. J. Anthropol. Sport Phys. Educ., 4(3):3-7, 2020.

Woodward, H.; Rutty, J. E. \& Rutty, G. N. A 51-year retrospective study of the trends of height, weight and body mass index at the time of death in those aged 16-103. J. Clin. Forensic Med., 8(2):66-73, 2001.

World Health Organization. Nutrition Landscape Information System (NLIS) Country Profile Indicators: Interpretation Guide. Geneva, World Health Organization, 2010.

\section{Corresponding Author: \\ Bojan Masanovic, PhD \\ University of Montenegro \\ Faculty for Sport and Physical Education \\ Narodneomladine bb \\ 81400 Niksic \\ MONTENEGRO}

\section{E-mail: bojanma@ucg.ac.me}

Received: 20-03-2021

Accepted: 13-05-2021 